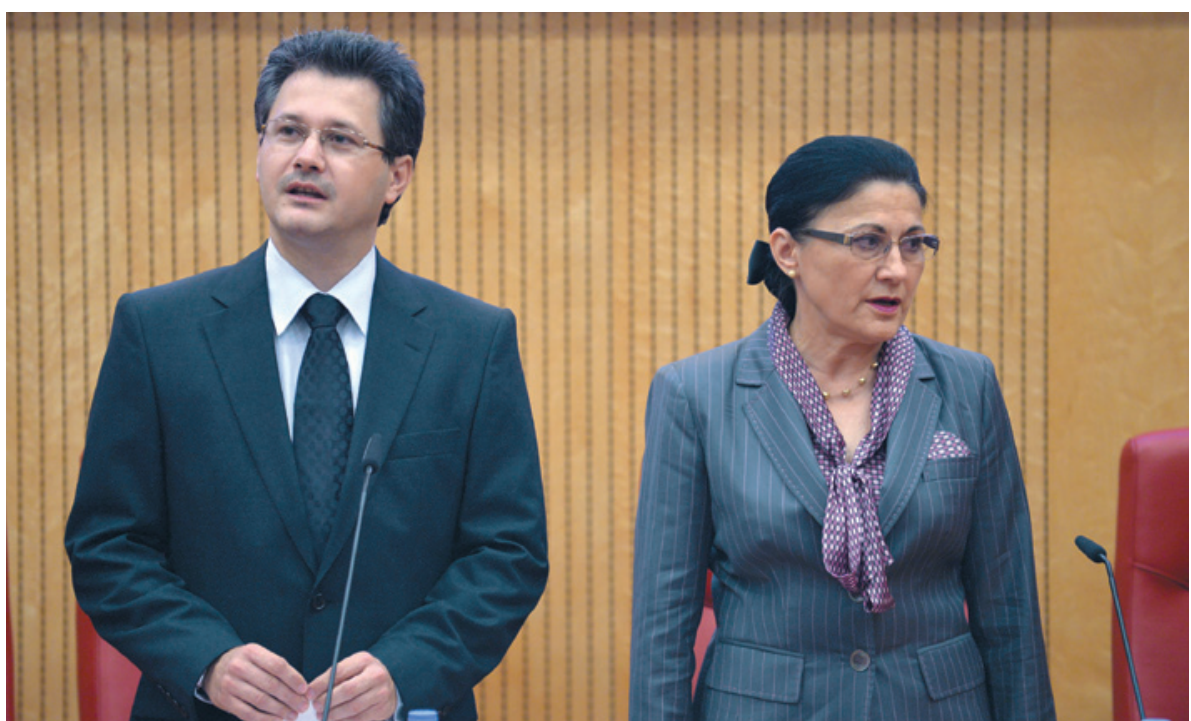

Research minister Mihnea Costoiu and his predecessor Ecaterina Andronescu have left scientists unhappy.

POLICY

\title{
Romanian science in free fall
}

\section{Researchers rue the reversal of positive reforms.}

\section{BY ALISON ABBOTT}

A fter 11 years away from Romania, developmental biologist Ioan Ovidiu Sirbu thought carefully before returning home to continue his scientific career. He had been convinced that reforms to Romania's cronyism-ridden research landscape were solid, particularly when, in 2011, government grants were for the first time ever allocated solely on the basis of performance.
"With such a fair granting system, I was sure that I could do my research just as well in Romania as in Germany," says Ovidiu Sirbu. "But what happened was really disappointing." Just months after Ovidiu Sirbu established himself at the Victor Babeş University of Medicine and Pharmacy in Timişoara in 2012, a new government slashed research funding and unpicked the reforms, eliminating rules designed to establish a meritocracy.

Ovidiu Sirbu's disappointment is widely shared. In April, hundreds of scientists took to the streets in protest, and more than 900 signed a petition addressed to Prime Minister Victor Ponta, demanding that the research budget and quality control be restored. The entire Nationa Research Council, Romania's main researchfunding agency, resigned in protest (see Nature 496, 274-275; 2013).

With no compromise from the government and the council seats still unfilled, Romanian science is adrift. Scientists are resigned to treading water, in the hope that the tide will turn.

Many of Romania's best researchers left during the political chaos that followed the collapse of communism in 1989. But in 2011, the government passed a law designed to drive up standards in education and science. Research and education minister Daniel Funeriu furnished the law with rules and regulations crafted to break through local power networks and ensure that funding and academic positions would go to the best people - for example by requiring grant applications to be reviewed by foreign experts, and by instituting minimum qualifications for job candidates (see Nature http:// doi.org/bp7nsg; 2011). At the same time, the research budget was boosted by nearly half.

But that government fell last year. Reversals to the reforms followed; many scientists blame Funeriu's successor, Ecaterina Andronescu.

Andronescu, who took the post last July, is a powerful figure in Romanian academic politics. She was research and education minister in two previous governments, and was rector at the Polytechnic University of Bucharest until she stepped down under Funeriu's conflict-ofinterest rules. The law forbade rectors from being politicians, in a bid to stop academics using political positions to help cronies.

Andronescu lost her ministerial post in fresh elections last December, but during her last days in office, she overhauled Funeriu's regulations using three legal tools - including an 'emergency ordinance, or decree, whose rationale, she declared, was a need to make standards attainable to more people. This decree is currently

\section{MISCONDUCT ALLEGATIONS}

\section{Plagiarism in politics}

Ecaterina Andronescu, Romania's former research and education minister, is a co-author of three out of four papers that international experts claim were plagiarized and infringe copyright. The allegations - the latest in a series of plagiarism scandals to rock Romania (see Nature http://doi.org/ngq; 2012) — were published last December on the scientist-run website Integru.org, which was set up with the aim of purging plagiarism from Romanian academia. The editors of the journals - Elsevier's Thin Solid Films and Journal of the European Ceramic Society, the
IEEE International Semiconductor Conference and the Romanian Academy's Romanian Journal of Information Science and Technology - were told a few days later.

The papers, published in 2006-07, have still not been retracted, says David Tománek, a physicist at Michigan State University in East Lansing, who reads Integru. He told Nature that the journals had not replied to requests for information from concerned scientists.

Only one editor - of Thin Solid Films responded to Nature's own requests for information. Joe Greene, a physicist at the
University of Illinois at Urbana-Champaign, wrote in an e-mail on 28 May that Elsevier had applied its own investigation procedures. He expected the inquiry to be concluded "within weeks to a couple of months".

Andronescu, who has not responded to Nature's written and telephone requests for comment on this particular issue, denied plagiarism in an interview published in a Romanian newspaper in May, adding that a representative from the Journal of the European Ceramic Society had called her just days earlier to congratulate her on a paper. A.A. 
being discussed in parliament. Andronescu's actions reversed safeguards against conflicts of interest and cronyism. Andronescu did not respond with comment on these specific concerns in time for Nature's press deadline.

Under the latest rules, university rectors can once more be members of parliament, and academics over the retirement age of 65 , including Andronescu herself, can hold leadership positions at universities - previously banned to stop people holding on to power for too long. Funeriu had limited academics to supervising eight $\mathrm{PhD}$ students at a time - to stop powerful professors from dominating the training of the next generation - but that restriction has now been lifted. And grant applications no longer require review by scientists outside Romania.

In addition, Andronescu abolished the requirement that professors pass a special exam, and loosened Funeriu's minimum criteria for holding an academic post. Critics slam the new criteria as too soft, and say that they are distorted in some subjects - in biology, for example, the focus is on publication of books rather than of peer-reviewed papers. The loosened criteria were applied this year in appointing 1,300 professors as part of Romania's first competition for academic posts since 2009.

Andronescu, who remains a member of parliament, is now head of the senate's education committee and leads her university's senate. She told Nature that responsibility for developing minimum criteria for academic appointments lies with the Romanian National Council for the Attestation of University Titles. The criteria then become official through ministerial order.

Late last year, Andronescu was embroiled in further controversy, owing to accusations of plagiarism and copyright infringement in her research papers (see 'Plagiarism in politics').

Her ministerial successor, Mihnea Costoiu, told Nature that all procedures for academic appointments had been correctly followed in this year's hiring surge. He added that assertions that standards for becoming a professor had been lowered were "either a misinterpretation or an uninformed assumption on the part of the 'initiators' of this theory".

In April, Costoiu made deep retrospective cuts to the basic research budget, roughly halving the value of grants awarded in 2011 that were already in progress, and stalling the next round of already-evaluated grants. $\mathrm{He}$ also launched a new grant competition, for collaborations between research and industry, using laxer rules. Costoiu says that he intends ongoing grants to receive their full monies in later years.

In spite of the tumult, Ovidiu Sirbu remains optimistic. A grant that he applied for in 2012 finally came through this month, although it had been cut by about one-quarter. And he thinks that by staying, he can make a small difference to science in Romania. "One of the good things is that I can train people the way they should be trained," he says. "That's the best I can do now in this country." -

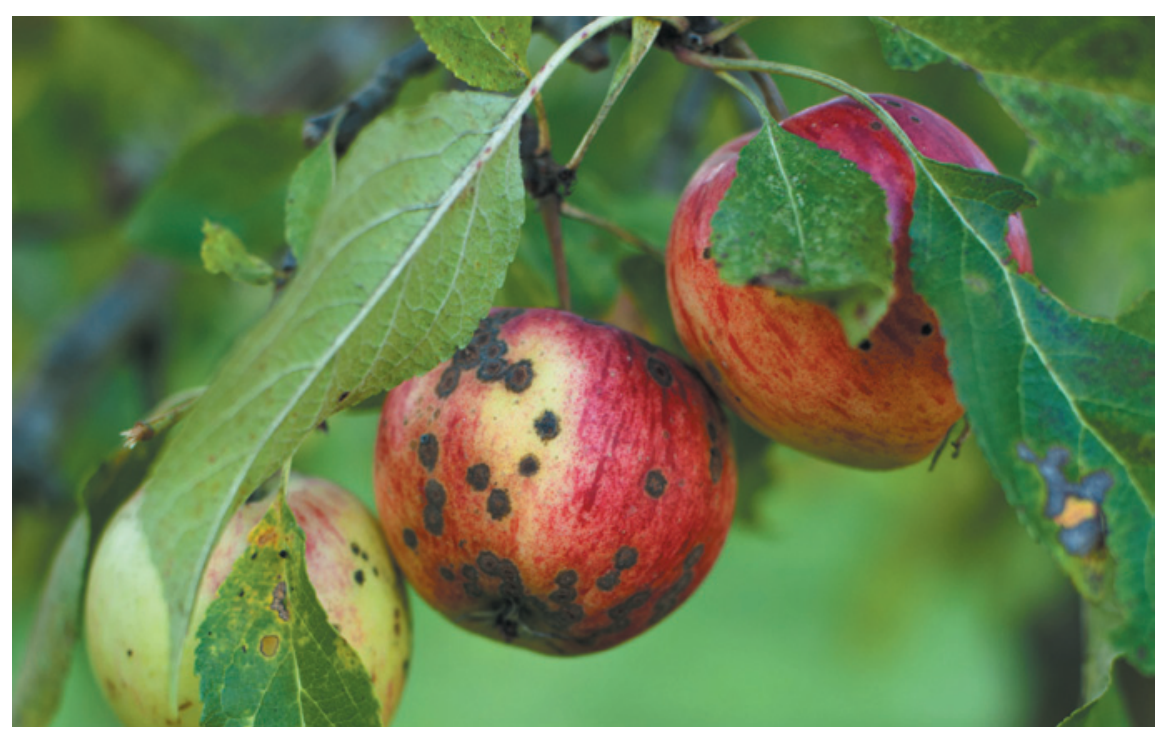

Apple scab is one of several crop diseases that researchers want to beat with genetic engineering.

\section{BIOTECHNOLOGY}

\section{US regulation misses some GM crops}

\section{Gaps in oversight of transgenic technologies allow scientists to test the waters for speciality varieties.}

\section{BY HEIDI LEDFORD}

$\mathrm{I}$ took scientists 85 years to breed a commercial apple that could fend off apple scab, a devastating disease caused by the fungus Venturia inaequalis. In 1999, they finally produced a tasty variety that contained the $V f$ defence gene, bred in from an unappetizing relative. Instead of dousing orchards with fungicides 30 times a season, farmers could spray the resistant crop just twice.

But five years later, $V$. inaequalis had evolved and apples trees were becoming infected again. Breeders were back to square one. Even armed with modern breeding techniques and 15 known defence genes in the apple family, it would take another 40 years to breed a resistant strain conventionally, says Henk Schouten, a plant scientist at Wageningen University in the Netherlands.

So instead, Schouten has joined a small but growing pool of academics and companies hoping to taking advantage of the latest approaches in genetic engineering, while avoiding the lengthy and expensive burden of government regulation. Because he wants to insert DNA only from related apple varieties, Schouten argues that his product should not be regulated in the same way as genetically modified (GM) crops that are engineered

with bacterial or viral DNA. Other pioneers argue that the techniques they are using to modify plants are safer than old technologies, and therefore do not need regulation. In some cases, US regulators have agreed.

Since 2010, the US Department of Agriculture has told at least 10 groups that their GM products would not require regulation (see 'Cropping out regulation') - removing a substantial financial barrier and speeding up development. That has encouraged academic labs and small companies to pursue speciality crops, such as apples, that have so far been ignored by biotechnology giants.

"There are any number of companies exploring new techniques to produce crops that don't trigger regulatory oversight," says Scott Thenell, managing director of Thenell \& Associates, a consulting firm in Walnut Creek, California, that helps researchers to navigate GM-plant regulations. "And often, they are small or niche crops that can't support the escalating costs of regulatory approval."

The regulation of GM crops in the United

DNATURE.COM For more on GM crops, see Nature's special issue: nature.com/gmcrops
States is based on laws that were not tailormade for the technology. The Animal and Plant Health Inspection Service (APHIS), 